\title{
SOME CONTRIBUTIONS OF METAVISUALIZATION IN CHEMICAL EDUCATION: A NEW FIELD OF RESEARCH
}

\section{Solange Locatelli}

Faculty of Education, University of Sao Paulo solangew1@ hotmail.com

\section{Agnaldo Arroio}

Faculty of Education, University of Sao Paulo

\begin{abstract}
Metavisualization is a fast-growing field in education, specifically in science, which involves the interpretation of external visualizations (images, for example) all the time, and is explained by models built by scientists. This review covers 17 articles published between 2008 and beginning of 2014, seeking to answer the question: "What has been presented in articles about metavisualization in teaching science?" Four categories were designed to classify the nature of the articles. Primary research targets were to look whether the article is of investigative or theoretical type, if the article involves some metavisual strategies or if it highlights its importance in the learning process. Major findings include: 1) the subject is still little explored; 2) most of the articles are the investigative type, and the data is collected with students; 3) just over half of papers involve a metavisual strategy or highlights the importance of metavisualization on the learning process. It is recommended that further studies are made on the subject, including the development of metavisual strategies that may help in the science learning process.
\end{abstract}

Key words: metavisual strategy; chemistry teaching, metacognition, metavisualization.

\section{Introduction}

Models are widely used in science teaching, which are available in various forms of external visualizations (pictures, graphs, drawings, etc.). This way, students will have to deal with mental models constructed in their mind (Locatelli, Ferreira \& Arroio, 2010), internal visualizations, to understand several representational modes, since for a better understanding of chemistry, it is considered necessary that the student transits in three representational levels (macroscopic, submicroscopic and representational) (Johnstone, 1993). In this case, representational is also called symbolic (Gilbert \& Treagust, 2009). Students who demonstrate difficulty to transfer between levels of information do not always explicitly consider these connections and, therefore, developing metavisual skills could assist them in this task (Chittleborough \& Treagust, 2008). Thus, research on the subject of metavisualization seems desirable to improve the understanding of the students in learning scientific concepts. What has been produced in research on this topic in journals of this field of knowledge? By reviewing literature on the topic of metavisualization, this study aimed at answering: "What has been presented in articles about metavisualization in teaching science?" The period chosen for the research was from 2008 to early 2014. 


\section{Theoretical Background}

\subsection{Visualization}

It is a new field of research and, according to Ayres, Ferreira \& Arroio (2010) we have more questions than answers in this field. Visualizations allow possibilities of building mental models for students (Rapp; Kurby, 2008). We can consider external and internal visualizations. The definitions are complex, but we can think of external visualizations as those available in the environment, some of these representations particularly developed for the educational environment as maps and graphics, for example. Internal visualizations are not in the environment. Unlike the external ones, they are developed in the learner's mind. In other words, everything that comes from the external environment for the student pictures, photos, images, graphics, tables, maps, drawings, etc. - are external visualizations. How they interact with what the student already knows is quite particular, varying from person to person. The image that results from this interaction, which is in the student's mind, is the internal visualization. It's hard to know how each student will interpret the information since each person takes their own values and identity, depending on their prior knowledge (Locatelli, 2014). However, according to Kosslyn (2006) some types of external visual representations have been more efficient in promoting relationship than other forms of representation, due to the use of concrete models and symbols. Gilbert (2010) exemplifies the importance of using verbal and non-verbal stimuli, such as speech and pictures, allowing cross-linking occurs between the different representations which can generate new connections, enhancing the learning process. Finally, Kozma \& Russell (2005) recommend the use of some visualization features (models, simulations, animations, for instance) to chemical education, as this may help the acquisition of representational skills in students and in laboratory activities, which are considered two important aspects in teaching this discipline.

\subsection{Metacognition}

It is a relatively new term in the literature, according to Flavell (1976). Although there is no single definition for metacognition and there exists many aspects to be considered, there is strong recognition of its importance in learning (Cooper; Sandi-Urena \& Stevens, 2008; Anderson; Nashon \& Thomas, 2007; Rickey \& Stacy, 2000). Metacognition involves the learner to be able to monitor, assess and self-regulate learning (Flavell, 1976). Complementing the setting, metacognition enables the awareness of own knowledge (White, 1988; Brown, 2006; Girash, 2014). This way of thinking has been widely used in recent research in science teaching and in the psychology educational area, where the emphasis is on the role of awareness. According to Locatelli (2014, p.24) metacognition can be assumed as "a series of processes involving the monitoring and the rethinking of one's knowledge, gradually leading to an increase in the autonomy of study and learning." Cooper, SandiUrena, \& Stevens (2008, p. 18) pointed out that "Metacognition is fundamental in achieving understanding of chemistry and developing of problem solving skills". To sum up, this 
concept involves more than thinking about one's own thinking, or cognition about cognition (Flavell, 1979) because it includes processes such as monitoring, evaluating and selfregulating learning (Flavell, 1976) and awareness (White 1988; Brown, 2006; Girash, 2014). According to Zohar \& Barzilai (2013), studies in metacognition are growing in science education, and one of the intended objectives in research has been the conceptual understanding of science. Also, metacognitive strategies and their limits have been explored. It is worth mentioning the shortcomings pointed out by these researchers, which is that metacognitive skills have been mostly researched, unlike the metacognitive knowledge, which is also important. There is a need for more studies showing the effectiveness of metacognition in the learning of science. Few studies exist with younger children and finally a lack of studies on metacognition and teacher training (Zohar \& Barzilai, 2013).

\subsection{Metavisualization}

Metacognition is an interface that includes many cognitive processes such as visualization; consequently, this approach has been denoted as metavisualization by Gilbert (2005). Nowadays the amount of information represented by external visualizations is very large and the students learn how to rebuild the ideas, making them to realize what is scientifically accepted. Jarman et al (2012) points out that while science teachers use newspaper images in their classes, for example, they often do not consider that students may have problems in the interpretation of them, which can lead to distorted ideas. This is increasing every day since newspaper reports are accompanied by many images (infographics, cartoons, etc). Moreover, they are relaying information just as the written word is (Jarman et al, 2012). Therefore, it shows up as a great challenge for science teachers to prepare the students for scientific literacy. Using a metavisual strategy in the classroom can help this task to support students' viewing, understanding and using scientific ideas or images. Locatelli \& Arroyo (2013) point to metavisualization as especially important in the teaching of science, and that visual skills seem to be a necessary condition for the student to become metavisual. Hence, the importance of considering teaching-learning strategies, also contemplating the use of visualizations and to think about them, appears as an intense metavisual exercise. As an example of metavisual strategy used, Locatelli \& Arroyo (2014) conducted an activity with the students starting their studies in electrochemistry. The students were asked to draw a representation of submicroscopic copper (II) ions interacting with iron atoms, two designs, one to represent the particles at the beginning (before the reaction) and later (after the reaction), placing subtitles in both designs. After that, they observed a drawing with a representation submitted by the researcher and had to compare it to theirs in order to find similarities and differences, helping them rebuild their ideas. "The findings show that the metavisual strategy may enable the reconstruction of ideas by students, leading them to a better understanding of the phenomenon studied and could contribute towards improving learning in electrochemistry." (Locatelli \& Arroio, 2014, p.14) 


\section{Research methodology}

To develop this research four criteria guided the selection of articles:

- Articles that has been used the term "metavisual" (same meaning in English, Portuguese and Spanish) in any parts of the text;

- The article should belong to a wide circulation of journals in science education and be indexed in international databases;

- Many of those that could be accessed for reading and analysis;

- The chosen period was from 2008 to early 2014, a time when the survey was conducted. The year 2008 was chosen because we did not find articles, within the criterion of the research, dated earlier than 2008.

Within this criterion, seventeen articles of seven journals of wide circulation in science education were found. The analysis considered the following descriptor, in order to identify the nature of the articles:

1. The journal in which the article was found.

2. Theoretical or Investigative type

- Theoretical (T), which contains review or theoretical discussion.

- Investigative (I), with research question and data collection with students in any school age.

In sequence, they were subdivided into:

1. Metavisual strategy or no metavisual strategy

- Metavisual strategy (ME): contains metavisual strategy for student learning or the article highlights the importance of metavisualization;

- No metavisual strategy (NME): ones that do not present a proposal for metavisual strategy to be developed with students, wherein metavisualization was cited, but only to some measure.

To sum up, to know the nature of the articles, they were classified as:

- T-ME: theoretical type and metavisual strategy.

- T-NME: theoretical type and no metavisual strategy.

- I-ME: investigative type and metavisual strategy.

- I-NME: investigative type and no metavisual strategy.

\section{Results and discussion}

\subsection{Periodic where articles were found:}

After the search for articles, seventeen were found that fulfilled the criteria described above. In total, the items were found in seven different journals, as can be seen in Table 1 . 


\begin{tabular}{lc}
\hline Journal & Number of articles \\
\hline International Journal of Science Education (IJSE) & 6 \\
Chemical Education Research and Practice (CERP) & 3 \\
Research in Science Education (RSE) & 3 \\
Problems of Education in the 21 $1^{\text {st }}$ century (PEC) & 2 \\
Brazilian journal of chemical education (REBEQ) & 1 \\
Eurasia Journal of Mathematics, Science \& Technology Education (EJMSTE) & 1 \\
Natural Science Education (NSE) & 1
\end{tabular}

Table 1: Names of journals and quantity of articles found in each of them.

As it can be seen, the largest number of articles was found in the International Journal of Science Education (IJSE), 35\% of the total. Of this total surveyed only one of them is in Portuguese (REBEQ), with all others being in English. It was found that no research in Spanish that would meet the proposed criteria for selection.

\subsection{Nature of each article, according to the descriptors: T (theoretical), I (investigative), ME (metavisual strategy) or NME (no metavisual strategy)}

\subsubsection{Description of the Table 2}

Following, each article was read, analyzed and classified according to their nature. The results are shown in Table 2. This table was divided in columns:

1. The article number from 1 to 17 ;

2. The names of the authors and the year of publication;

3. The title of the article.

4. The journal, volume and number in parentheses (when necessary) and the first page of the article.

5. Classification in theoretical (T) or investigative (I) type.

6. Classification in metavisual strategy (ME) or no metavisual strategy (NME)

7. Article Nature, making the joint classification of items in columns 5 and 6. 


\begin{tabular}{|c|c|c|c|c|c|c|}
\hline $1^{\mathrm{a}}$ & $2^{a}$ & $3^{a}$ & $4^{a}$ & $5^{a}$ & $6^{a}$ & $7^{a}$ \\
\hline & Autor/Year & Title & Journal & T or I & $\begin{array}{l}\text { ME } \\
\text { or } \\
\text { NME }\end{array}$ & $\begin{array}{l}\text { Nature } \\
\text { of the } \\
\text { article }\end{array}$ \\
\hline 1 & $\begin{array}{l}\text { Cooper, Sandi- } \\
\text { Urena, \& } \\
\text { Stevens, } 2008\end{array}$ & $\begin{array}{l}\text { Reliable multi method assessment of } \\
\text { metacognition use in chemistry } \\
\text { problem solving }\end{array}$ & $\begin{array}{l}\text { CERP, 9, p. } \\
18\end{array}$ & I & NME & I-NME \\
\hline 2 & $\begin{array}{l}\text { Chittleborough } \\
\& \text { Treagust, } \\
2008\end{array}$ & $\begin{array}{l}\text { Correct Interpretation of Chemical } \\
\text { Diagrams Requires Transforming } \\
\text { from One Level of Representation to } \\
\text { Another }\end{array}$ & $\begin{array}{l}\text { RSE, 38, } \\
\text { p.463 }\end{array}$ & I & $\mathrm{ME}$ & I-ME \\
\hline 3 & $\begin{array}{l}\text { Maia \& Justi, } \\
2009\end{array}$ & $\begin{array}{l}\text { Learning of Chemical Equilibrium } \\
\text { through Modelling-based Teaching }\end{array}$ & $\begin{array}{l}\text { IJSE, 31(5), } \\
\text { p.603 }\end{array}$ & I & ME & I-ME \\
\hline 4 & Brooks, 2009 & $\begin{array}{l}\text { Drawing, Visualisation and Young } \\
\text { Children's Exploration of "Big } \\
\text { Ideas" }\end{array}$ & $\begin{array}{l}\text { IJSE, 31(3), } \\
\text { p.319 }\end{array}$ & $\mathrm{T}$ & ME & T-ME \\
\hline 5 & $\begin{array}{l}\text { Ayres, } \\
\text { Ferreira, \& } \\
\text { Arroio, } 2010\end{array}$ & $\begin{array}{l}\text { The usage of a simulation to study } \\
\text { intermolecular forces: some } \\
\text { findings. }\end{array}$ & $\begin{array}{l}\text { PEC, 24, } \\
\text { p.19 }\end{array}$ & I & NME & I-NME \\
\hline 6 & $\begin{array}{l}\text { Locatelli, } \\
\text { Ferreira \& } \\
\text { Arroio, } 2010\end{array}$ & $\begin{array}{l}\text { Metavisualization: an important skill } \\
\text { in the learning chemistry }\end{array}$ & $\begin{array}{l}\text { PEC, } 24, \\
\text { p.75 }\end{array}$ & $\mathrm{T}$ & ME & T-ME \\
\hline 7 & $\begin{array}{l}\text { Hand \& Choi, } \\
2010\end{array}$ & $\begin{array}{l}\text { Examining the Impact of Student } \\
\text { Use of Multiple Modal } \\
\text { Representations in Constructing } \\
\text { Arguments in Organic Chemistry } \\
\text { Laboratory Classes }\end{array}$ & $\begin{array}{l}\text { RSE, } 40, \\
\text { p. } 29\end{array}$ & I & $\mathrm{ME}$ & I-ME \\
\hline 8 & $\begin{array}{l}\text { Eilam \& } \\
\text { Poyas, } 2010\end{array}$ & $\begin{array}{l}\text { External Visual Representations in } \\
\text { Science Learning: The case of } \\
\text { relations among system components }\end{array}$ & $\begin{array}{l}\text { IJSE, } 32 \\
(17) \\
\text { p. } 2335\end{array}$ & I & NME & I-NME \\
\hline 9 & $\begin{array}{l}\text { Locatelli \& } \\
\text { Arroio, } 2011\end{array}$ & $\begin{array}{l}\text { Designing Molecules and Thinking } \\
\text { About Them: metavisual skill in the } \\
\text { teaching of Geometrical Isomerism }\end{array}$ & $\begin{array}{l}\text { REBEQ, } \\
6(1,2), \text { p.99 }\end{array}$ & I & ME & I-ME \\
\hline $\begin{array}{l}1 \\
0\end{array}$ & $\begin{array}{l}\text { Madden, Jones } \\
\text { \& Rahm, } 2011\end{array}$ & $\begin{array}{l}\text { The role of multiple representations } \\
\text { in the understanding of ideal gas } \\
\text { problems }\end{array}$ & $\begin{array}{l}\text { CERP, } 17, \\
\text { p. } 283\end{array}$ & I & NME & I-NME \\
\hline $\begin{array}{l}1 \\
1\end{array}$ & $\begin{array}{l}\text { Jarman, Clune, } \\
\text { Pyle \& } \\
\text { Braband, } 2011\end{array}$ & $\begin{array}{l}\text { The Critical Reading of the Images } \\
\text { Associated with Science-Related } \\
\text { News Reports: Establishing a } \\
\text { knowledge, skills, and attitudes } \\
\text { framework }\end{array}$ & $\begin{array}{l}\text { IJSE, 2(2), } \\
\text { p.103 }\end{array}$ & $\mathrm{T}$ & NME & T-NME \\
\hline $\begin{array}{l}1 \\
2\end{array}$ & $\begin{array}{l}\text { Oh \& Oh, } \\
2011\end{array}$ & $\begin{array}{l}\text { What Teachers of Science Need to } \\
\text { Know about Models: An overview }\end{array}$ & $\begin{array}{l}\text { IJSE, 33(8), } \\
\text { p.1109 }\end{array}$ & $\mathrm{T}$ & ME & T-ME \\
\hline $\begin{array}{l}1 \\
3\end{array}$ & $\begin{array}{l}\text { Wang \& } \\
\text { Barrow, } 2011\end{array}$ & $\begin{array}{l}\text { Characteristics and Levels of } \\
\text { sophistication: An Analysis of } \\
\text { Chemistry Students' Ability to } \\
\text { Think with Mental Models }\end{array}$ & $\begin{array}{l}\text { RSE, 41, } \\
\text { p.561 }\end{array}$ & I & ME & $\mathrm{I}-\mathrm{ME}$ \\
\hline
\end{tabular}




\begin{tabular}{|c|c|c|c|c|c|c|}
\hline 4 & $\begin{array}{l}\text { Locatelli, } \\
\text { Arroio, } 2013\end{array}$ & $\begin{array}{l}\text { Metacognition and chemical } \\
\text { education: an experience in teaching } \\
\text { geometrical isomerism }\end{array}$ & $\begin{array}{l}\text { NSE, 2(37), } \\
\text { p.18 }\end{array}$ & I & $\mathrm{ME}$ & I-ME \\
\hline $\begin{array}{l}1 \\
5\end{array}$ & Balushi,2013 & $\begin{array}{l}\text { The Effect of Different Textual } \\
\text { Narrations on } \\
\text { Students` Explanations at the } \\
\text { Submicroscopic Level in chemistry }\end{array}$ & $\begin{array}{l}\text { EJMSTE, } \\
9(1), \text { p.3 }\end{array}$ & I & NME & I-NME \\
\hline $\begin{array}{l}1 \\
6\end{array}$ & $\begin{array}{l}\text { Balushi \& } \\
\text { Ajri, } 2014\end{array}$ & $\begin{array}{l}\text { Associating animations with } \\
\text { concrete models to enhance } \\
\text { students' comprehension of different } \\
\text { visual representations in organic } \\
\text { chemistry }\end{array}$ & $\begin{array}{l}\text { CERP, } 15, \\
\text { p. } 47\end{array}$ & I & NME & I-NME \\
\hline $\begin{array}{l}1 \\
7\end{array}$ & $\begin{array}{l}\text { Taskin \& } \\
\text { Bernholt, } 2014\end{array}$ & $\begin{array}{l}\text { Students' Understanding of } \\
\text { Chemical } \\
\text { Formulae: A review of empirical } \\
\text { research }\end{array}$ & $\begin{array}{l}\text { IJSE, 36(1), } \\
\text { p.157 }\end{array}$ & $\mathrm{T}$ & NME & T-NME \\
\hline
\end{tabular}

\subsubsection{Number of researchers involved in the studies}

In the 17 articles selected for the analysis, we found 28 researchers who were involved, and 2 of them in two different articles on the subject, one of them in 3 articles and a researcher involved in 4 articles. This seems to suggest that there is still a small group researching the subject.

\subsubsection{Analysis of the nature of the items properly}

To facilitate this analysis, the nature of the articles (7th column) was included in Figure 1:

\section{Nature of articles}

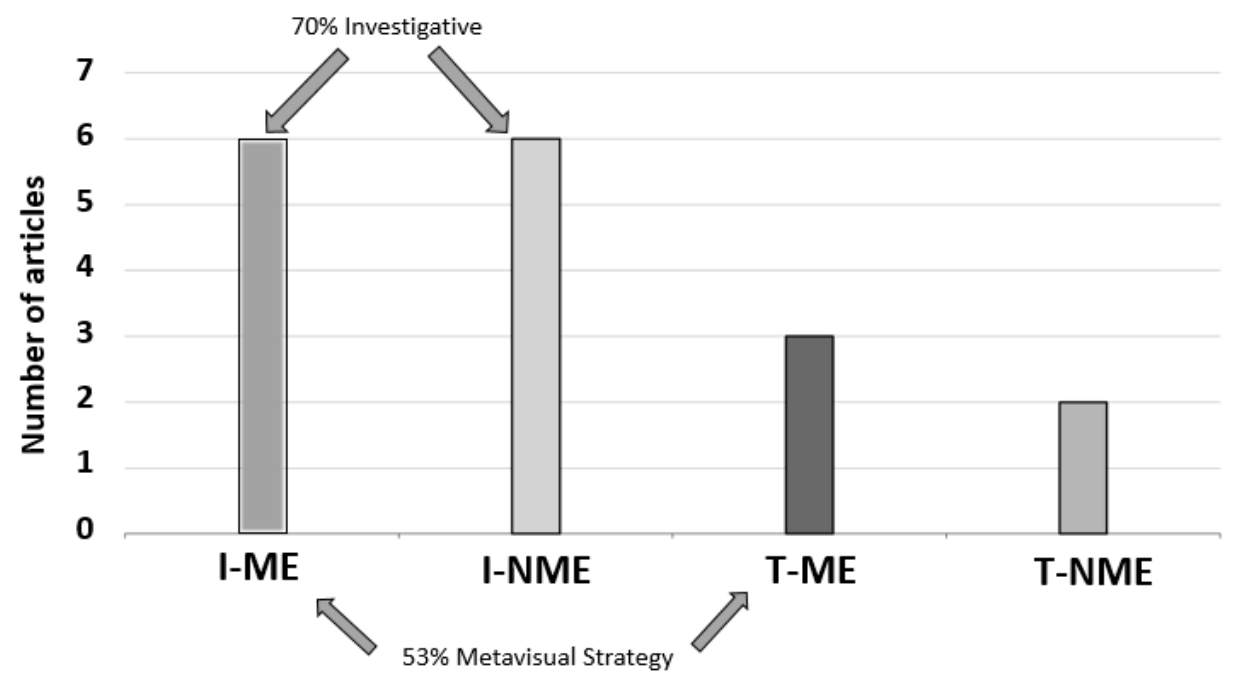

Figure 1: Nature of the articles

As shown in Figure 1, it was found that most of the articles on the topic is of investigative type (I-ME and I-NME), 70\%. More than half of them (53\%) use metavisual strategies (I-ME and T-ME) or highlight its importance. It is worth pointing out the presence of approximately 
$29 \%$ of theoretical articles, which can be considered a good signal, since it is desirable to develop a theory that supports the practice, which can help increasing its understanding.

\section{Conclusion}

It can be concluded that there is still a very small number of articles on metavisualization, most of them being the investigative type (about 70\%). all of the articles indicate the presence of metavisualization on science education research. IJSE is the journal with the highest incidence in this study, with $35 \%$ of the analyzed articles. Metavisual strategies are already used in many of them (53\%) which may indicate small advances in research and the use of this kind of strategy in science education. It must be noted that that this study has its limitations, as it was based on the term metavisualization. It is important also to note that many researchers have used other terms and these were not included in this work. Here the focus was solemnly on studies where metacognitive processes, i.e. rebuilding of concepts from the rethinking of ideas, which have been denoted under the term of metavisualization by the authors. Another limitation was that only articles in English, Spanish and Portuguese language were looked for. However, it can be noticed that the topic is very recent and still needs a lot of research and insights on how metavisualization can aid in learning science. Also, inclusion of other terms connected to the metavisualization process would point to a wider view of current understanding of the process itself in the practice of science education. 


\section{References}

Anderson, D., Nashon, S., \& Thomas, G. (2007). Evolution of research methods for probing and understanding metacognition. Research in Science Education, 39(2), pp. 181-195.

Ayres, C., Ferreira, C., \& Arroio, A. (2010). The usage of a simulation to study intermolecular forces: some findings. Problems of education in the 21st century, pp. 19-29.

Brown, N. (2006). The development of a questionnaire assessing metacognitive patterns of students majoring in accounting in higher education. Accounting education: an interantional journal, 15(3), pp. 301-323.

Chittleborough, G., \& Treagust, D. (2008). Correct Interpretation of Chemical Diagrams Requires Transforming from One Level of Representation to Another. Research Science Education, 38, pp. 463-482.

Cooper, M. M., Sandi-Urena, S., \& Stevens, R. (2008). Reliable multi method assessment of metacognition use in chemistry problem solving. Chemical education research and Practice, 9, pp. 18-24.

Flavell, J. (1976). Metacognitive aspects of problem solving. Em L. R. (orgs), The nature of intelligence (pp. 231-235).

Flavell, J. (1979). Metacognition and cognitive monitoring: A new area of cognitive-developmental Inquiry. American Psychologist, 34, pp. 906-911.

Gilbert, J. (2005). Visualization: A Metacognitive Skill in Science and Science Education. Em J. G. (Eds), Visualization in Science Education (pp. 9-27).

Gilbert, J. K. (2010). The role of visual representations in the learning and teaching of science: An introduction. Asia-Pacific Forum on Science Learning and Teaching,, 1O(1), pp. 1-19.

Gilbert, J., \& treagust, D. (2009). Introduction: macro, submicro and symbolic representations and the relationship between them: key models in chemical education. Em J. Gilbert, \& D. (. Treagust, Multiple representations in chemical education (Vol. 4, pp. 1-8).

Girash, J. (2014). Metacognition and Instruction. Em V. Benassi, O. C, \& C. (. Hakala, Applying science of learning in education (pp. 152-168). Washington D.C.

Jarman, R., Clune, B., Pyle, E., \& Braband, G. (2012). The Critical Reading of the Images associated with science related news report: establishing a knowledge, skills, and attitudes framework. International Journal of Science Education, 2(2), pp. 103-129.

Johnstone, A. (1993). The development of chemistry teaching: a changing response to a changing demand. Journal of Chemical Education, 7o(9), pp. 701-705.

Kosslyn, S. M. (2006). Graph design for the eye and mind. New York: New York: Oxford University Press.

Kozma, R., \& J, R. (2005). Modelling students becoming chemists: Developing representational competence. Em J. K. Gilbert, Visualization in Science Education (pp. 121-146). Springer.

Locatelli, S. (2014). Tópicos de metacognição: para aprender e ensinar melhor. Sao Paulo: Appris.

Locatelli, S., \& Arroio, A. (2013). Metacognition and Chemical education: an experience in teaching geometrical isomerism. Natural Science Education, 37(2), pp. 18-26.

Locatelli, S., \& Arroio, A. (2014). Metavisual strategy assisting the learning of initial concepts of electrochemical. Natural Science Education, 39(1), pp. 14-24.

Locatelli, S., Ferreira, C., \& Arroio, A. (2010). Metavisualization: an important skill in the learning chemistry. Problems of Education in the 21st Century, 24, pp. 75-83.

Rapp, D., \& Kurby, C. (2008). The 'Ins' and 'Outs' of Learning: Internal Representations and External Visualizations. Em J. e. Gilbert, Visualization: theory and practice in science education (pp. 2952).

Rickey, D., \& Stacy, A. (2000). The role of metacognition in learning chemistry. Journal of Chemical Education, 77(7), pp. 915-920. 
White, R. (1988). Metacognition. Em J. (. Keeve, Educational research, methodology and measurement: an international handbook (pp. 70-75). Oxford: Pergamon.

Zohar, A., \& Barzilai, S. (2013). A review of research on metacognition in science education: current and future directions. Studies in Science Education, 49(2), pp. 121-169. 